\title{
A critical view on social performance assessment at company level: social life cycle analysis of an algae case
}

\author{
Parisa Rafiaani ${ }^{1,2}$ (D) Tom Kuppens ${ }^{1} \cdot$ Gwenny Thomassen $^{1,3,4,5} \cdot$ Miet Van Dael $^{1,3} \cdot$ Hossein Azadi $^{1,2,6}$. \\ Philippe Lebailly ${ }^{2} \cdot$ Steven Van Passel ${ }^{1,5}$
}

Received: 15 June 2019 / Accepted: 8 October 2019

(C) Springer-Verlag GmbH Germany, part of Springer Nature 2019

\begin{abstract}
Purpose Social indicators are not easy to be quantitatively analyzed, although at the local scale, the social impacts might be relevant and important. Using the existing approaches for both quantitative and semi-qualitative measurements, this study aims to assess the social impacts of a company working on algae production systems in Belgium through social life cycle analysis (SLCA). By highlighting the opportunities and challenges on the way of applying the existing SLCA approaches at company level, the objective of this study is to contribute to the development of a suitable and clear SLCA approach when a company is considered as the unit of analysis.

Methods Based on the list of potential social impact categories suggested by the United Nations Environment Program/Society of Environmental Toxicology and Chemistry (UNEP/SETAC) guidelines (2009) for SLCA, three stakeholder groups (workers, consumers, and local community) and three subcategories associated with each stakeholder group were identified as the most relevant for carbon capture and utilization technologies. Company and sector level data were collected using existing documents and reports, and the data were analyzed and scored using a combined quantitative and semi-quantitative approach to develop a social assessment model for the case study.

Results and discussion The company appears to perform well for all the evaluated social indicators except the one related to the subcategory "equal opportunity/discrimination for workers" for which the share of women employed is lower compared with the sector-level data. The results of our assessment were further discussed regarding the challenges and limitations of performing SLCA at the company level. Based on our experience, the validity of the outcomes is significantly influenced by the data availability, the generality of the indicators introduced within the UNEP/SETAC guidelines, and the subjectivity in data collection for the semi-quantitative assessment among others.

Conclusions By highlighting the difficulties and challenges of applying the SLCA at the company level, our study provides a starting point for improving the quantitative assessment and monitoring social implications at the company level within a regional foreground in Europe.
\end{abstract}

Keywords Algae $\cdot \mathrm{CO}_{2} \cdot$ Life cycle $\cdot$ Social indicator $\cdot$ Sustainability

Responsible editor: Marzia Traverso

Parisa Rafiaani

parisa.rafiaani@uhasselt.be

1 UHasselt-Hasselt University, Centre for Environmental Sciences, Agoralaan, 3590 Diepenbeek, Belgium

2 Economics and Rural Development, Gembloux Agro-Bio Tech, University of Liège, 5030 Gembloux, Belgium
3 Unit Separation and Conversion Technologies, VITO, Boeretang 200, 2400 Mol, Belgium

4 Research Group Sustainable Systems Engineering (STEN), Ghent University, Coupure Links 653, 9000 Ghent, Belgium

5 Department of Engineering Management, University of Antwerp, Prinsstraat 13, 2000 Antwerp, Belgium

6 Department of Geography, Ghent University, Krijgslaan, 281 S8, 9000 Ghent, Belgium 


\section{Introduction}

Microalgae have recently gained growing interest as a resource for energy production, pharmaceuticals, and nutrition (Khan et al. 2018) due to their high photosynthesis ability, rapid growth, significant biomass yield, and useful lipid extractions in comparison with other energy crops (Koller et al. 2012). A small number of microalgae, however, are generated on an industrial scale during the last few decades (Gouveia et al. 2008; Khan et al. 2018; Plaza et al. 2009). The main species for biotechnological usages are the green algae (Chlorophycea) Chlorella vulgari and Dunaliella salina and cyanobacteria Spirulina maxima, which are generated mainly as either supplement for food or feed (Spruijt 2017). These are examples of biobased products that may influence society and the environment both positively and negatively. The potential impacts may happen along the whole life cycle of the biobased products and can be related to the biomass production phase and biorefinery (and linked) processes such as cultivation, harvesting, and drying. Generally, algae cultivation systems can be categorized into either open or closed photobioreactors through which microalgae can capture $\mathrm{CO}_{2}$ as a source of carbon for photosynthesis (Wilson et al. 2016). This can be seen as carbon capture and utilization (CCU) for which typically, the potential impacts are calculated in terms of economic and technical indices while social factors are usually neglected in the majority of impact assessments in the past (Falcone and Imbert 2018; Rafiaani et al. 2018). This is due to the fact that most of these innovative technologies are in the research and development (R\&D) stage, at lower technology readiness levels (TRLs), and the market for such innovative technologies is still growing (Yang et al. 2015). Consequently, there is a lack of data with regard to the potential social impacts. Nevertheless, algae-derived products are becoming more commercialized, and since their production requires a large amount of $\mathrm{CO}_{2}$, nutrients, electricity, and other chemical substances, production of algae biomass will have an impact on local and regional levels, comprising environmental, social, and economic effects (Khan et al. 2018; Yang et al. 2015). Along with the technology enhancements and the increasing number of innovative project development worldwide, the market potential for algae-based products is growing. Consequently, comprehensive sustainability assessments are needed, including social pillars to steer the development of such biobased products.

From a full sustainability assessment point of view, to date, several studies conducted either the techno-economic assessment (TEA) (Abdul Hamid and Lim 2018; Idris et al. 2017; Thomassen et al. 2016; Rizwan et al. 2015) or the environmental assessment (Wu et al. 2018; Gnansounou and Raman 2016; Handler et al. 2014; Campbell et al. 2011) of algaebased biorefineries. The integration of environmental assessment to a TEA model of an algae case has been done by
Thomassen et al. (2018) with highlighting the importance of the integration of social dimension of sustainability in such assessment models. This integration would be an added value to achieve a full sustainability analysis for such innovative technologies (Rafiaani et al. 2018). Life cycle thinking including social life cycle analysis (SLCA) gives the possibility of effective evaluations which will result in more sustainable, economic, social, and environmental outcomes (Siebert et al. 2018; Spierling et al. 2018). The United Nations Environment Program/Society of Environmental Toxicology and Chemistry (UNEP/SETAC) guidelines (2009) for SLCA is one of the most commonly applied approaches for social impact evaluation of companies and products from the life cycle perspective (Ekener-Petersen et al. 2014; Martínez-Blanco et al. 2014; Siebert et al. 2018).

Many potential social impacts have an economic background (Hasenheit et al. 2016) in a way that one single production process can have different impacts linked to the economic context of the process location. Increasing incomes, new markets, and production procedures, for instance, have potentially positive influences on health, employment, and food security. These kinds of socioeconomic impacts are very much related to the technology itself (Hasenheit et al. 2016), and researchers have highlighted such connections (Zamalloa et al. 2011; Menetrez 2012; Yang et al. 2015). Falcone and Imbert (2018) conducted a review on SLCA studies on biobased products and highlighted that health and rights of workers and contribution to employment are the most common indicators in those studies whereas other indicators like community involvement are less addressed. Moreover, in their latest study, Falcone et al. (2019) identified the relevant social indicators for SLCA of biobased products based on the UNEP/SETAC guidelines (2009) using a stakeholder participatory approach. Based on their results, health and safety, decent work, labor and human rights, and social acceptability were identified as the most relevant impact categories to be considered for a SLCA of biobased products. Similarly, Omann (2007) referred to the importance of labor concerns such as safety problems, fair wages, and equal chances to be addressed when evaluating social impacts. Raj-Reichert (2013) identified the health and safety conditions in industries as one of the major employee concerns in the electronics industry. Alvarez-ChÁvez et al. (2012) have considered the workplace-related health and safety impacts of bioplastics along their life cycle. Montero et al. (2009) emphasized that some employers do not consider or are not even aware of their responsibilities regarding occupational health and safety of their workers. Zhu et al. (2015) emphasized the importance of economic, social, and cultural aspects of algal biofuels and highlighted the fact that there are no recommendations on enhancing these aspects or that only some specific indicators have been measured so far for this pillar. For instance, socioeconomic indicators of sustainability were not considered in the report of the National Research Council (NRC) (2012) on sustainable 
development of algal biofuels except for the energy return on investment that was mentioned in that report. Food security maintenance without influencing the agricultural land availability is usually highlighted as a common advantage (NRC 2012; Daroch et al. 2013) although no quantitative measurement has been done for that. To conclude, one can say that the socioeconomic impacts of algal systems have not been assessed comprehensively so far. Specifically, the social assessments in the literature were mostly qualitative and/or only a review was conducted on potential indicators for the socioeconomic assessment of algae systems (Efroymson et al. 2017) and the effects on job creation linked with building up and implementing an algal biofuel manufacturing site have been carried out so far (Madugu 2015). Calculated indicators at small-scale studies are usually not public and more likely encompass employment and workers' salaries and workdays lost due to injury (Efroymson et al. 2017). Most of the proposed indicators for social impacts in the literature are not yet quantified in existing sustainability assessment literature for algae-based biorefineries and infrastructures (Efroymson et al. 2017).

From a company perspective, Jørgensen et al. (2008) found that there is no awareness among the companies of the term social assessments, including impacts on workers, society, and consumers. Besides, the nature of impacts that companies thought about was basically according to the International Labour Organization (ILO) and Human Rights conventions or other available international agreements they had to follow (Jørgensen et al. 2008). It was also discussed that the companies usually do not want to draw attention to the potentially negative impacts in the downstream chain (i.e., manufacturing, usage, and end-of-life options) (Jørgensen et al. 2008). Furthermore, according to a recent study conducted by Siebert et al. (2018), there are no SLCA studies collecting data for indicators at company level throughout production systems and neither quantifying them using sector/regional references (Siebert et al. 2018). Specifically, there is also no empirical SLCA on the performance of a company active in algae production systems although some case studies can be found in other industries within the bioeconomy (Foolmaun and Ramjeeawon (2013) for plastics; Aparcana and Salhofer (2013) for recycling systems). With regard to the suitability of SLCA within a company context, different SLCA approaches are proposed, for example, by Dreyer et al. (2006) and Manhart and Grießhammer (2006) who suggested an SLCA approach in order to determine the potential for enhancements along the life cycle of a product/service. From a business perspective, Dreyer et al. (2006) stated that companies need to take responsibility for the humans influenced by their implementations as well as being able to compete and make profits to remain in the competitive market. This calls for an SLCA assisting companies to perform in a socially responsible context through presenting reports on their potential social impacts. Martínez-Blanco et al. (2015) also proposed an organizational approach to SLCA called Social Organizational Life Cycle Assessment (SOLCA), which mainly focuses on improving the scope and inventory steps of the SLCA. They further discussed the importance of taking an organizational perspective into account for linking the social impact and indicators to the organization's performance. A comparative SLCA approach was also suggested by Schmidt et al. (2004) and Spillemaeckers et al. (2004) developed a social labelling tool considering mostly the upstream phase of the life cycle. A social responsibility investment tool was also proposed by Méthot (2005) from a life cycle perspective. However, to the best of our knowledge, it is not clear based on the literature and reports' documents to what extent these suggested approaches are applied or requested by companies. Martínez-Blanco et al. (2015) argue that there is a need to make SLCA more applicable by using an organizational perspective instead of a product perspective in analyzing social impacts. Therefore, it can be concluded that the usage of SLCA from a company perspective is limited.

There is a lack of empirical research on the social impacts of algae systems at company levels. To fill this gap, this study aims to evaluate the feasibility, level of risks, and opportunities of existing approaches for measuring social impacts at the company scale. By highlighting the opportunities and challenges for applying SLCA at company level, the objective of our study is to contribute to the development of a suitable and clear SLCA approach when a company is considered as the unit of analysis. Accordingly, the social impacts of a Belgian company active in algae biomass production were assessed as an example to apply SLCA using both quantitative and semiquantitative measurements. The results of our assessment are further discussed from a critical point of view regarding the broadness of social indicators, data collection difficulties and challenges at the company level, and the limitation of the existing approaches and their feasible implementation. In Section 5, some recommendations for future studies are provided. Our assessment follows the main steps of SLCA introduced by the UNEP/SETAC guidelines (2009), which are explained in the following section.

\section{Methodology}

The UNEP/SETAC guidelines (2009) developed an SLCA approach following the same general four steps of environmental life cycle assessment (LCA) as indicated by ISO 14040/14044 (ISO 2006). The SLCA conducted in this study is described below based on the UNEP/SETAC guidelines (2009), i.e., (i) goal and scope definition; (ii) inventory analysis; (iii) impact assessment; and (iv) interpretation. In this section, each of these steps including the goal, the case study, and the methods carried out for assessing the social performance is further elaborated. 


\subsection{Goal and scope: SLCA at the company level}

As an example of a company involved in algae biomass production within the European context, a chemical company in Belgium has been selected. The company is active for a decade and has a manufacturing plant with around 250 staff members in which the algae team encompasses a small size. The company produces chemicals as well as biobased products, including algae as freeze-dried biomass for use as animal feed mainly for medium-scale niche markets. The microalgae department of the company has nine employees. The boundary of our study is limited to the production of algae biomass taking into account a cradle-to-gate perspective, i.e., the life cycle stages from the microalgae cultivation to the point at which algae biomass is extracted and leaves the manufacture gate (i.e., excluding transport, use, and end-of-life phases) (Fig. 1). The production process uses a closed photobioreactor consisting of a large transparent bag with embedded plastic panels in which the algae grow. The microalgae obtain their carbon from $\mathrm{CO}_{2}$ bottles through a fan. With regard to the functional unit, the working hours are usually utilized in existing SLCA literature as a linkage between the social performance and the functional unit (Bouzid and Padilla 2014; Martínez-Blanco et al. 2014; Traverso et al. 2018). However, it is argued that this method only considers the workers group and not the other stakeholder involved within a life cycle under consideration (Martínez-Blanco et al. 2014; Hannouf and Assefa 2018). Since social impacts in our study are related to the company performance and are gathered at the company level, our outcomes demonstrate the social performance of the company responsible for the various unit processes involved along the algae production stages. This approach was also applied by Hannouf and Assefa (2018) and Petti et al. (2018). Similarly, Martínez-Blanco et al. (2015) defined the organization under study as the functional unit of analysis through the SOLCA approach and discussed that linking social impacts to the company under study instead of the product sounds more practical, rational, and feasible. This can be supported through referring to the previous SLCA case studies where there is a failure in clear linkage between the outcomes of the analysis to a particular product level as the defined reference unit (see for example, Dreyer et al. (2006); Franze and Ciroth 2011; Hosseinijou et al. 2014). Therefore, as it is suggested by SOLCA, the company under study is assigned as the functional unit for conducting SLCA from a company perspective.

\subsection{Inventory analysis: selecting subcategories and indicators for data collection}

In order to rank the entire list of subcategories and indicators (UNEP/SECTAC 2009) based on their relevance to CCU, 33 European CCU experts responded to an online questionnaire in July 2017. The complete versions of the questionnaires are provided in the section of the Electronic Supplementary Material. The results of the survey were analyzed using a multi-criteria decision-making tool (Rafiaani et al. 2019). In the UNEP/SETAC (2009), subcategories and, accordingly, the indicators are defined related to each stakeholder group. The selected stakeholder groups include workers, consumers, and the local community based on the defined system boundary. The World Business Council for Sustainable Development (WBCSD 2016) also introduced these three groups as the targeted stakeholders for SLCA of chemical products. Based on the results of the survey study (Rafiaani et al. 2019), the subcategories and their related indicators that rank higher were selected for further assessment in the present study (Table 1). The results cover the following main subcategories: regarding the workers group: "fair salary"; "health and safety"; and "equal opportunities/discrimination"; for the consumer group: "end of life responsibility"; "transparency"; and "health and safety"; for the local community group: "safe and healthy living conditions"; "secure living conditions"; and "local employment." Similar to our ranking, Falcone et al. (2019) identified all the abovementioned subcategories as the most relevant ones to be included in the SLCA of biobased products.

For data collection, we first investigated the annual reports from the company (2012-2017) for available social data regarding the indicators of the above-identified subcategories at the company level. Performance reference points (PRPs) method applies as an impact assessment method in SLCA for which the collected social data are compared with the thresholds such as the minimum acceptable performance level at the sector/country scale (Parent et al. 2010). This assists in identifying the magnitude and significance of the collected data (UNEP/SETAC 2009). This method is highlighted as

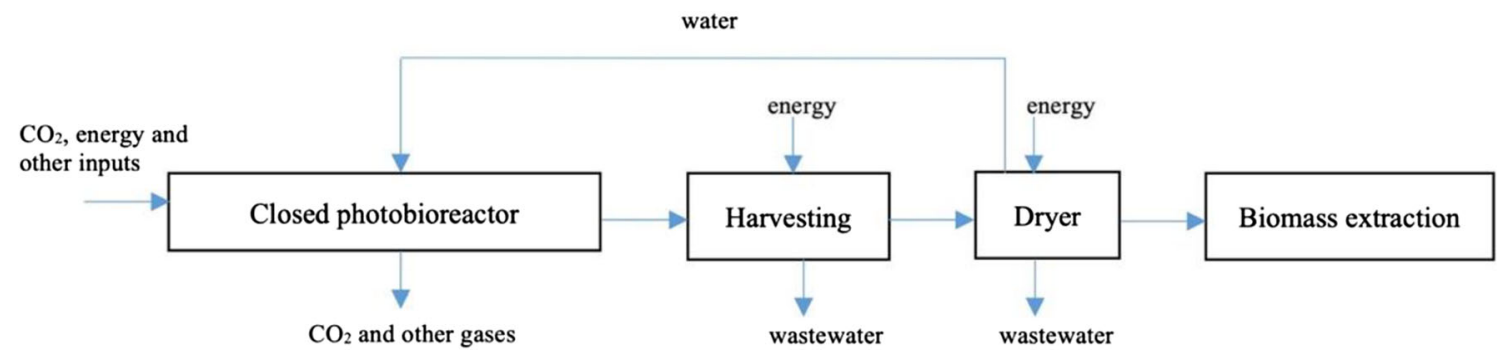

Fig. 1 System process boundary 
Table 1 Stakeholders, subcategories, and indicators for SLCA (UNEP/SETAC 2009)

\begin{tabular}{llll}
\hline Group Subcategory & Description & $\begin{array}{l}\text { Indicator (the most relevant Characteristic } \\
\text { indicators identified in }\end{array}$ & $\begin{array}{l}\text { Social } \\
\text { impact } \\
\text { Rafiaani et al. (working } \\
\text { paper)) }\end{array}$ \\
& direction
\end{tabular}

\begin{tabular}{|c|c|c|c|c|c|}
\hline \multirow[t]{3}{*}{ Worker } & Fair salary for workers & $\begin{array}{l}\text { "Living wage defines the adequate income } \\
\text { standard, i.e., the gross monthly wage } \\
\text { needed to cover the required living costs of } \\
\text { an individual or a family" (WageIndicator } \\
\text { Foundation 2018). The statutory minimum } \\
\text { wages are defined by law or government } \\
\text { regulations and thus consider both the right } \\
\text { of the worker and the obligation of the } \\
\text { employer. Whereas, living wages are not } \\
\text { provided by law and cannot be legally } \\
\text { applied. If the paid wage from the } \\
\text { company is equal to or exceeds the } \\
\text { minimum wage in the sector/industry } \\
\text { where the company is located, then the } \\
\text { wage is fair. }\end{array}$ & Fair wages for workers & Quantitative & Positive \\
\hline & Health and safety of workers & $\begin{array}{l}\text { The compliance of the company performance } \\
\text { with the measures on health and safety and } \\
\text { that there is the prevention of diseases } \\
\text { and/or injuries in the work environment } \\
\text { (Lenzo et al. 2017). }\end{array}$ & $\begin{array}{l}\text { Average number of work } \\
\text { days lost per worker per } \\
\text { year }\end{array}$ & Quantitative & Negative \\
\hline & $\begin{array}{l}\text { Equal } \\
\text { opportunities/- } \\
\text { discrimination for workers }\end{array}$ & $\begin{array}{l}\text { The company's capability to treat all its } \\
\text { employees in an equal way, no } \\
\text { discrimination due to nationality, gender, }\end{array}$ & $\begin{array}{l}\text { Rate of female to male } \\
\text { employees }\end{array}$ & Quantitative & Positive \\
\hline
\end{tabular}

Local
$\begin{aligned} & \text { Safe and healthy living } \\ & \text { nity }\end{aligned}$

Secure living conditions

Local employment Consumers End of life responsibility of
consumers

Transparency of the company discrimination due to nationality, gender, and/or other personal features (Lenzo et al. 2017).

Company's activities can influence community safety via equipment accidents or structural problems. This is a measure of the company's impact on community safety and health and showing if the company communicates their potential operational health impacts to the neighbor communities (UNEP/SETAC, 20013).

Companies may implement security necessities as a safeguard for their employees and properties. However, these security considerations should be in line with and/or increase the human rights protection in surrounding communities (Benoît et al. 2010).

The company's interest in hiring local workers and to use/collaborate with local suppliers (Lenzo et al. 2017).

End-of-life refers to disposal, reuse, or recycling of the end product of the company. From an environmental perspective, this is usually referred to as Extended Producer Responsibility (UNEP/SETAC 2013).

Companies' transparency gives the right to consumers to make a conscious choice without deceiving/covering up the intention of the company. There are certification, labels, and particular indicators that may be applied to generate information about performance with regard to social responsibility (UNEP/SETAC 2013).
Control measures for maintenance operations involving hazardous substances

Number of injuries per year associated to the company conditions

Percentage of workforce hired locally

Clear information provided by internal management systems to consumers on end-of-life options

Certification/label the company obtained for the product/site
Semi-quantitative Positive

Semi-quantitative Negative Semi-quantitative Positive

Sen

Semi-quantitative Positive 
Table 1 (continued)

\begin{tabular}{llll}
\hline Group Subcategory & Description & $\begin{array}{l}\text { Indicator (the most relevant } \\
\text { indicators identified in } \\
\text { Rafiani et al. (working } \\
\text { paper)) }\end{array}$ & $\begin{array}{c}\text { Characteristic } \\
\text { Social } \\
\text { impact } \\
\text { direction }\end{array}$ \\
\hline Consumers health and safety & $\begin{array}{l}\text { It refers to the consumer's protection rights } \\
\text { against hazardous products and services } \\
\text { (ISO 26000, 2010) that may cause harm to } \\
\text { their health and safety (UNEP/SETAC } \\
\text { 2013). }\end{array}$ & $\begin{array}{l}\text { Quality of labels of health } \\
\text { and safety requirements }\end{array}$ \\
\hline
\end{tabular}

the more accurate one for site-specific (company level) data (Prasara-A and Gheewala 2018). As we need PRPs for evaluating the performance at the company level in our study, data for the same indicators at the sector and country levels was collected through the available literature and documents (the company annual reports (2012-2017); Essencia 2017; Neugebauer et al. 2017; UNDP 2018; WageIndicator Foundation 2018). To confirm the results and to search any contradiction that could exist owing to the subjective nature of the social data, the company was contacted via mail and telephone conversation with the product manager, managing director, and human resource manager. The company confirmed that the figures in their annual reports are accurate and no further information was available on the social indicators at the time of our research.

\subsection{Impact assessment: measurement approaches for calculating and scoring the indicators}

In our study, the 3 indicators related to the subcategories of the worker's group of stakeholders including "fair salary," "health and safety," and "equal opportunities/discrimination" are quantitatively measured since the quantitative data were available at company and sector/country levels for calculation of the impacts. However, the indicators related to the consumer and local community groups are considered as semiquantitative due to the lack of quantitative data for these groups. Accordingly, both quantitative and semi-quantitative measurement approaches are suggested for calculating and scoring the social impact indicators in order to develop a comparable social impact analysis. These approaches are described in this section.

\subsubsection{Semi-quantitative measurement}

To tackle the issue of the data availability mentioned above, a semi-quantitative approach is employed to assess social impacts related to the indicators of consumer and local community groups. This is consistent with the study conducted by Aparcana and Salhofer (2013), Dreyer et al. (2006), Jørgensen et al. (2008), and Wang et al. (2016) who applied semi- quantitative approaches for SLCA. Many previous SLCA studies (Ciroth and Franze 2011; Traverso et al., 2012; Aparcana and Salhofer (2013); Vinyes et al. 2013; Foolmaun and Ramjeeawon 2013) assumed all social subcategories and related indicators to be equally important. The Economic Commission for Europe (2018) and Traverso et al. (2012) mention that giving the same importance to the social indicators makes the interpretation transparent and simple for users. In contrast, there are other studies in which a weighting system was applied for SLCA (see, for example, Schmidt et al. 2004; Manik et al. 2013; Wang et al. 2016; van Haaster et al. 2017). In fact, defining the weights becomes important if aggregation and/or making composite indicators are the main focus of the analysis in order to allow decisionmaking (Traverso et al., 2012; Manik et al. 2013; ChhipiShrestha and Rehan Sadiq 2015; Telles do Carmo et al. 2016; Garrido et al. 2018; Ofori Agyekum et al. 2017). Such a decision is beyond the goal and scope of our study. Moreover, there is no consensus among the SLCA community on appropriate weighting systems (Chhipi-Shrestha and Rehan Sadiq 2015). Greco et al. (2019) also mentioned that inadequate knowledge and practical evidences, lack of theoretical framework in developing weighing scheme, and lack of consensus among decision-makers are other general reasons for choosing equal weighting in the existing (social) sustainability studies. For the reasons mentioned above, no weighting system has been applied in our analysis. This is in line with previous SLCA studies conducted by Dreyer et al. (2010), Franze and Ciroth (2011), Martínez-Blanco et al. 2014, and Ekener-Petersen and Finnveden (2013) who also applied no weighting system in their analysis.

In following the UNEP/SETAC (2009) as the main approach of our SLCA study, a semi-quantitative method called subcategory assessment method (SAM) was applied, which also takes into account the subcategories and indicators envisaged in the UNEP/SETAC (2009) guidelines. SAM is seen as a semi-quantitative method as it can transform qualitative into quantitative data. There are a few studies working on (semi)quantitative social impacts from the life cycle perspective in different sectors (Martínez-Blanco et al. (2014) for mineral fertilizers and industrial compost; Traverso et al. 
(2012b) for photovoltaic modules production; Ugaya et al. (2011) for cocoa soap). SAM has already been carried out in other sectors (e.g., Hannouf and Assefa (2018) for polyethylene production; Ramirez et al. (2016) for cocoa soap production) whereas there is no application of SAM for SLCA of companies performing algae biomass production. SAM has a four-level scale from 1 to 4 (the higher the better) for assessing the impact of each indicator to simplify the assessment across a system (Table 2).

This method is considered as a characterization objective model in analyzing the company performance over the life cycle of a product/system in relation to the basic requirement (BR) fulfillment which is considered as a reference point. In this study, the BR defined by Ramirez et al. (2014) is applied. Their definitions are based on the SLCA methodological sheets (UNEP/SETAC 2013), international agreements, existing regulations, and the company management efforts/ policies. Four defined levels of the SAM (Table 3) are as follows: the first level, however, needed to be reserved for a company with proactive performance regarding the BR along the whole supply chain and would correspond to level A. Indeed, level A applies when the company promotes the BR to its suppliers or other stakeholders in the value chain so that they also meet the BR of the related indicator (Ramirez et al. 2014). For example, with regard to transparency, a company receives an A if it encourages its suppliers to provide social responsibility reports. Accordingly, the company makes a report in accordance to the guidelines of the Global Compact and Global Reporting Initiative (GRI) in which it also involves the performances of its suppliers. Given that, level A could not be applied within the defined system boundary of our study because it is not clear if the value chain initiatives are well-developed yet and if the company is promoting the BR of the indicators among all its suppliers. There is no evidence of such encouragements within their annual public reports. The second level (B) refers to companies that meet the $\mathrm{BR}$; the levels $\mathrm{C}$ and $\mathrm{D}$ are assigned to the companies that do not meet the BR taking the company's social context into account (Ramirez et al. 2014). This consideration is crucial, as a company operating in a negative context may have greater difficulty in implementing social actions. For example, the equal opportunity issues can be met easier in a country with a positive setting than in a country with the opposite situation as the one in a positive context is stimulated to meet the international agreement requirements (Ramirez et al. 2014). Accordingly, levels C and D refer to a company that does not fulfill the BR and performing in a positive and negative context, respectively (Ramirez et al. 2014).

\subsubsection{Quantitative measurement}

For the three quantitative indicators, the scoring approach proposed by Wang et al. (2016) is considered as the baseline for our study (Table 4). Originally, they proposed a scoring system with 5 levels. However, the score levels developed by Wang et al. (2016) are slightly modified in our study to be in 4 levels. This modification was needed because the scoring in SAM is comprised of 4 levels, and in order to make a comparable scoring between both quantitative and semi-quantitative measurements, the levels for quantitative scoring needed to be modified. In this approach, company data and sector/country level data are needed for scoring the social impact. Accordingly, the available statistical data on quantitative indicators at the sector level is considered as PRPs based on the data from Belgian "chemicals, plastics, and life sciences" industry (Essencia 2017). This quantitative approach is in line with Nef (2004) and Wang et al. (2016), who used government statistics and other formal data related to sector/country levels to evaluate the companies' performance from the social perspective.

As the following table shows, a score of 1 to 4 is assigned to each quantitative indicator based on the proportion between the inventory data from a company and the statistical data at the sector level in Belgium. For the positive impact indicator, a score of 1 to 4 within four levels denotes a proportion of less than 50,50 to 100,100 to 150 , and more than $150 \%$, respectively. By contrast, for the negative impact indicator, a score of 1 to 4 corresponds to a proportion of more than 150,100 to 150,50 to 100 , and less than $50 \%$, respectively. This assessment approach was applied to two indicators of the worker group including "health and safety of workers" and "equal opportunities/discrimination for workers."
Table 2 Definition of the assessment levels in subcategory assessment method (SAM) (Ramirez et al. 2014)

\begin{tabular}{|c|c|c|c|}
\hline Level & Description & Score & Score's definition \\
\hline A & $\begin{array}{l}\text { The company has a proactive performance in relation } \\
\text { to the BR along all the value chain linked to each } \\
\text { subcategory }\end{array}$ & 4 & Very good performance \\
\hline B & The company meets the BR & 3 & Satisfactory performance \\
\hline $\mathrm{C}$ & $\begin{array}{l}\text { The company does not meet the BR; it is situated in } \\
\text { a desirable context to the fulfillment of BR }\end{array}$ & 2 & Inadequate performance \\
\hline $\mathrm{D}$ & $\begin{array}{l}\text { The company does not meet the BR-it is situated in } \\
\text { an undesirable context to the fulfillment of BR }\end{array}$ & 1 & Bad performance \\
\hline
\end{tabular}

$B R$, basic requirement 
Table 3 Description of the SAM scale for the stakeholder groups (adapted from Ramirez et al. 2014)

\begin{tabular}{|c|c|c|c|c|}
\hline Group & Subcategory & Basic requirement (level B) & Defining level C and level D & Reference \\
\hline Worker & Fair salary & $\begin{array}{l}\text { The lowest wage is equal to/higher than the } \\
\text { minimum living wage in the sector/country where } \\
\text { the company is placed. }\end{array}$ & $\begin{array}{l}\text { Based on the calculation for fair wage introduced } \\
\text { by Neugebauer et al. (2017), values } \geq 1 \text { are } \\
\text { considered as fair as the company paid wage } \\
\text { suits or is even more than the minimum living } \\
\text { wage. The company is assessed at level C if the } \\
\text { value is equal to the minimum living wage. } \\
\text { Values }<1 \text { are interpreted as insufficient and } \\
\text { considered as underpayments, as worker's } \\
\text { family may not be able to meet the living } \\
\text { standard or may live in poverty (D). }\end{array}$ & $\begin{array}{l}\text { Neugebauer } \\
\text { et al. } \\
\text { (2017) }\end{array}$ \\
\hline \multirow[t]{3}{*}{$\begin{array}{l}\text { Local } \\
\text { commu- } \\
\text { nity }\end{array}$} & $\begin{array}{l}\text { Safe and } \\
\text { healthy } \\
\text { living } \\
\text { conditions }\end{array}$ & $\begin{array}{l}\text { Evidence that the company has environmental risk } \\
\text { management schemes or cooperates with local } \\
\text { companies in communicating the possible } \\
\text { operational health and safety impacts on neighbor } \\
\text { communities (UNEP/SETAC 2013). }\end{array}$ & $\begin{array}{l}\text { Age-standardized disability-adjusted life year } \\
\text { (DALY) rate (WHO 2019) which is expressed as } \\
\text { the number of years lost due to ill-health, } \\
\text { disability, or early death. Country that is rated at } \\
\text { a value equal to/less than } 20,000 \text { is assessed as C } \\
\text { and if it is rated at a value more than } 20,000 \text { is } \\
\text { assessed as D. }\end{array}$ & $\begin{array}{l}\text { Country } \\
\text { indexes }\end{array}$ \\
\hline & $\begin{array}{c}\text { Secure living } \\
\text { conditions }\end{array}$ & $\begin{array}{l}\text { Evidence of conflicts between the local community } \\
\text { and company that may put their secure living } \\
\text { conditions in danger (UNEP/SETAC 2013). }\end{array}$ & $\begin{array}{l}\text { Country rank in safety perception based on the } \\
\text { method suggested by UNDP (2010). This is a } \\
\text { measure for the quality of "civic and community } \\
\text { wellbeing." Country with the perception of } \\
\text { safety percentage equal to or higher than } 50 \text { is } \\
\text { assessed as C. Otherwise, the company is } \\
\text { assessed at level D. }\end{array}$ & \\
\hline & $\begin{array}{l}\text { Local } \\
\text { employ- } \\
\text { ment }\end{array}$ & $\begin{array}{l}\text { Evidence that the company has a policy of local } \\
\text { hiring preferences }\end{array}$ & $\begin{array}{l}\text { Employment to population ratio (KILM, 2012) } \\
\text { which is defined as the proportion of a country's } \\
\text { working-age population that is employed } \\
\text { (KILM 2012). A country with the ratio lower } \\
\text { than } 50 \text { (“i"); and those with the ratio equal to or } \\
\text { higher than } 50 \text { ("j"). A company that does not } \\
\text { meet the BR in a country ranked at " } \mathrm{j} \text { " is } \\
\text { assessed at level C. Otherwise, the company is } \\
\text { assessed at level D. }\end{array}$ & \\
\hline \multirow[t]{3}{*}{ Consumers } & $\begin{array}{l}\text { End of life } \\
\text { responsibil- } \\
\text { ity of } \\
\text { consumers }\end{array}$ & $\begin{array}{l}\text { Clear information is given by internal management } \\
\text { systems to consumers on end-of-life options such } \\
\text { as Product Responsibility Performance Indicators, } \\
\text { PR4 (GRI 2006) or a recall policy for its product at } \\
\text { its end-of-life phase }\end{array}$ & $\begin{array}{l}\text { (if applicable for end product) it is necessary to } \\
\text { know if the product is recycled (level C). } \\
\text { Otherwise, the company is assessed at level D. }\end{array}$ & \multirow{3}{*}{$\begin{array}{l}\text { Evidence } \\
\text { from the } \\
\text { company } \\
\text { manage- } \\
\text { ment }\end{array}$} \\
\hline & $\begin{array}{l}\text { Transparency } \\
\text { of the } \\
\text { company }\end{array}$ & $\begin{array}{l}\text { Presence of social responsibility reports such as } \\
\text { corporate social responsibility (CSR), social } \\
\text { balance report, Global Reporting Initiative (GRI), } \\
\text { Accountability } 1000 \text {, Social Accountability } 8000 \text {, } \\
\text { ISO } 26000 \text {, or any other internationally } \\
\text { recognized documentation }\end{array}$ & $\begin{array}{l}\text { The company evinces practices of management to } \\
\text { communicate with its consumers, such as } \\
\text { through public events or web site information } \\
\text { (level C). Otherwise, the company is assessed at } \\
\text { level D. }\end{array}$ & \\
\hline & $\begin{array}{l}\text { Consumers } \\
\text { Health and } \\
\text { Safety }\end{array}$ & Procedures regarding health and safety standards & $\begin{array}{l}\text { The company does not have proven instances of } \\
\text { breach of consumer health and safety in the last } \\
3 \text { years (level C). Otherwise, the company is } \\
\text { assessed at level D. }\end{array}$ & \\
\hline
\end{tabular}

Calculation for the indicator "fair salary" With regard to the fair salary indicator within the workers' group, first a characterization model suggested by Neugebauer et al. (2017) was applied in order to quantitatively measure this indicator. Neugebauer et al. (2017) provided a comprehensive review/discussion on the importance of fair wage along the SLCA and highlighted that a quantitative characterization model is missing in the literature for measuring fair wages. As discussed in the SLCA methodological sheet (UNEP/SETAC 2013) and other researches (Anker
2011; Neugebauer et al. 2014; Musaazi et al. 2015), three parameters including working time, equal remuneration, and living wage need to be taken into account for the concept of fair wage. Based on these three parameters, i.e., working time, equal remuneration, and living wages, Neugebauer et al. (2017) developed a quantitative characterization model and required dataset which is employed in our study. Using this model, we end up with a final value (and not a ratio between company and sector level data as suggested in the quantitative scoring approach). 
Table 4 Score system for quantitative indicators for SLCA (modified from Wang et al. 2016)

\begin{tabular}{|c|c|c|c|c|c|}
\hline \multirow[t]{2}{*}{ Indicator } & \multirow[t]{2}{*}{ Industry data (PRPs) } & \multirow[t]{2}{*}{ Company data } & \multirow{2}{*}{$\begin{array}{l}\text { Social } \\
\text { impact } \\
\text { percentage }^{a} \\
(\%)\end{array}$} & \multicolumn{2}{|l|}{ Score } \\
\hline & & & & $\begin{array}{l}\text { Positive } \\
\text { indicator }\end{array}$ & $\begin{array}{l}\text { Negative } \\
\text { indicator }\end{array}$ \\
\hline \multirow{4}{*}{$\begin{array}{l}\text { Indicator's } \\
\text { name }\end{array}$} & \multirow{4}{*}{$\begin{array}{l}\text { Statistical data from Belgian } \\
\text { chemicals, plastics, and } \\
\text { life sciences industry } \\
\text { reported in Essenscia } \\
\text { (2017) }\end{array}$} & \multirow{4}{*}{$\begin{array}{l}\text { Statistical data } \\
\text { reported in the } \\
\text { annual reports of } \\
\text { the company under } \\
\text { consideration }\end{array}$} & 0 to 50 & 1 & 4 \\
\hline & & & 50 to 100 & 2 & 3 \\
\hline & & & 100 to 150 & 3 & 2 \\
\hline & & & $>150$ & 4 & 1 \\
\hline
\end{tabular}

${ }^{\text {a }}$ Social impact percentage $=$ company data/industry data
Therefore, SAM is used for scoring the value of this specific indicator. In the characterization model, the real wage paid by the company to the workers is compared with a minimum (living) wage. Moreover, it relates wage to the effective working time and incorporates an inequality factor (if applicable) to measure income inequalities (Eqs. (1) and (2)).

$\mathrm{FWP} n=\frac{\mathrm{RW} n}{\mathrm{RWT} n} \times C F F W n$

$C F F W n=\frac{1}{\mathrm{MLW} n} \times \mathrm{CWT} n \times(1-\mathrm{IEF} n 2)$

For the calculation of CFFWn, regionalized characterization factors are used (i.e., the minimum living wage $\left(\mathrm{MLW}_{n}\right)$ characterizing the real wage $\left(\mathrm{RW}_{n}\right)$; the contracted working time $\left(\mathrm{CWT}_{n}\right)$ characterizing the inverse fraction of real working time $\left(\mathrm{RWT}_{n}\right)$; and a squared income inequality factor $\left(\mathrm{IEF}_{n}\right)$ accounting for differences in income) and the final calculated value of CFFWn is employed in Eq. (1) for measuring the "fair salary" indicator $\left(\mathrm{FWP}_{n}\right)$ (Neugebauer et al. 2017).

$\mathrm{FWP} n=\frac{\mathrm{RW} n}{\mathrm{MLW} n} \times \frac{\mathrm{CWT} n}{\mathrm{RWT} n} \times(1-\mathrm{IEF} n 2)$

All the parameters in one mathematical equation are read as follows (Neugebauer et al. 2017):

$\mathrm{FWP}_{n}$ is the fair wage potential representing process $n$ (production process in our study).

$\mathrm{RW}_{n}$ is the real (average) wage $(€ /$ month accounted over 1 year), which is paid to the worker(s) employed in the process $n$.

$\mathrm{RWT}_{n}$ is the real working time (hours/week) of workers operating process $n$ (comprising vacation days and unpaid overtime).

$\mathrm{MLW}_{n}$ is the minimum living wage (€/month), which has to be paid to the worker to be able to meet the normal living standard for an individual and/or family in the country where process $n$ is operated.
$\mathrm{CWT}_{n}$ is the contracted working time per country or sector (hours/week) for workers operating process $n$ (with counting vacation days).

$\mathrm{IEF}_{n}$ (squared) is the inequality factor (in percentages) of the company, region, or country, where process $n$ is operated.

$\mathrm{CF}_{\mathrm{FW} n}$ is the fair wage regionalized characterization factor (month/€) for process $n$ representing the country or sector-specific situations (Neugebauer et al. 2017).

Since the sector/country data are used for our measurements due to the lack of data at the company level, Gini coefficients need to be used as a proxy for $\mathrm{IEF}_{n}$ (Neugebauer et al. 2017). A Gini coefficient is a value between 0 and 1 calculating inequality in the income distribution for a country (FAO 2006). There are practical reasons for using the Gini index: it is generally known as a calculation of income inequality in countries; worldwide Gini coefficients are readily available for all countries around the world (Neugebauer et al. 2017). A value of 0 for the Gini index reflects complete equality while a value of 1 shows complete inequality. Accordingly, with these equations, a process-specific fair wage potential (FWP) can be accounted using the value 1 as the turning point in a way that values $\geq$ 1 are defined as fair, as the actual wage suits or even exceeds the minimum living wages (MLW) and values $<1$ are interpreted as to be not adequate and might contribute to the underpayment issues, as the family of workers may be not able to meet the living standard or even live under the poverty line (Neugebauer et al. 2017). Anker (2011) also discussed the significance of MLW, and how it relates to the condition of the country and working time, considering the contracted normal working time. Therefore, the direct correlation between the real wage (RW) and the MLW makes it possible to have a simple interpretation of an adequate wage level (Neugebauer et al. 2017).

Calculation for the indicator "safety of workers" There are potential accident risks related to different sectors and throughout different phases of the life cycle of a product specially biomass production (Siebert et al. 2018). Health and 
Table 5 Parameters for the calculation of the fair wage potential (FWP)

\begin{tabular}{|c|c|c|c|}
\hline Parameter & Description & Data & Data source \\
\hline RW & Real (average) wages ( $€ /$ month accounted over one year) & 4154 & Essenscia $^{1}(2017)$ \\
\hline RWT & Real working time (hours/week) & 37.5 (average country data) & Neugebauer et al. (2017) \\
\hline $\mathrm{CF}_{\mathrm{FW}}$ & $\begin{array}{l}\text { Fair wage-related characterization factor (month/€) } \\
\text { (regionalized) }\end{array}$ & Calculated using Eq. (2) & Neugebauer et al. (2017) \\
\hline MLW & Minimum living wage ( $€ /$ month) per individual ${ }^{2}$ & $\begin{array}{l}1502 \text { (min average wage) } \\
\text { (country data) }\end{array}$ & $\begin{array}{r}\text { WageIndicator Foundation (2017); } \\
\text { European Salary Survey (2017) }\end{array}$ \\
\hline CWT & $\begin{array}{l}\text { Contracted working time including country-specific } \\
\text { statutory working hours and vacation days (hours/week) }\end{array}$ & 39 & Neugebauer et al. (2017) \\
\hline $\mathrm{IEF}^{3}$ & $\begin{array}{l}\text { Inequality factor (in percentages) of the company, } \\
\text { region, or country }\end{array}$ & $\begin{array}{l}\text { Gini index (for the year 2017) } \\
\quad=0.27\end{array}$ & UNDP (2018) \\
\hline
\end{tabular}

\footnotetext{
${ }^{1}$ Gross monthly salary (full-time employees) in the Belgian chemicals and life science per month in 2015. This average gross salary is an average of $18.3 \%$ higher than in other manufacturing sectors. This is due to the fact that the chemicals and life sciences industry has a higher share of qualified and specialized employees than other sectors (Essenscia 2017)

${ }^{2}$ The individual living wage represents the amount of money needed to support a household with a single individual without children and employed fulltime (Guzi and Kahanec 2018)

${ }^{3}$ If the company data was used, there is no need to make a correction using the IEF, as they lie more than the average wage paid by sector and country (Neugebauer et al. 2017)
}

safety consideration become one of the key social issues to be considered in social assessments in a way that a company's activities should not cause any damage or negative impacts on the workers' health. As Table 6 shows, in our study, the workdays lost due to an injury is a measure for this subcategory and we calculated it through lost time accident (LTA) frequency rate. This measure is one of the most commonly used indicators to evaluate the accidents related to occupational safety and health at a company. It is defined as the amount/number of lost time accidents, that is, accidents occurring in the workplace and resulting in an employee's inability to work at least the next full workday. The accident occurs in a given period relative to the total number of hours worked in the accounting period which is usually calculated as follows (Chang and Wang 1995):

$\mathrm{LTA}=\frac{(\text { Number of lost time accident in the reporting period }) \times 1,000,000}{\text { Total hours worked in the reporting period }}$

\subsection{Interpretation}

Baumann and Tillman (2004) defined the interpretation step of the life cycle assessment as the evaluation of results to elicit conclusions. The results of the quantitative and semi-quantitative analyses are assessed together in order to highlight the main outcomes of our analysis. Finally, conclusions are drawn in relation to the defined goal and scope of the study. Based on the results of the study, the possibility of improving the social performance of those indicators showing low impacts is provided in Section 4.

\section{Results}

This section will give an overview of the results of both quantitative and semi-quantitative assessments.

\subsection{Quantitative measures}

\subsubsection{Fair salary for workers}

Following the characterization model suggested by Neugebauer et al. (2017) (Eqs. (1) to (3)), the fair salary status was calculated for the production process performed by the company under consideration focusing on the core groups of workers, including operators, technicians, and the management and administration. The required data were collected at the sector level as no data was available at the company level (Table 5). In the case of our study company, located in Belgium, it can be argued that due to sectorial wage negations, the average differences between companies in a sector are rather limited. As such, sector level data can be used if specific company level is not available. The value for MLW is calculated by the WageIndicator Foundation (2018) which is based on a survey approach for identifying a countryspecific basket of products ${ }^{1}$ for a better reflection of the actual requirements of the country-specific local context. The rest of the required values for the characterization model were extracted using the recently updated model/dataset developed by Neugebauer et al. (2017). ${ }^{2}$ They extracted the required data

\footnotetext{
${ }^{1}$ The calculation of living wage by WageIndicator Foundation considers the following six components: food, housing, transportation, health, education, and other expenditures (e.g., clothing, personal care), all in the local context. More information on https://wageindicator.org/salary/living-wage/belgiumliving-wage-series-december-2018

${ }^{2}$ Database can be downloaded free of charge from https://www.see.tuberlin. $\mathrm{de} /$ menue/forschung/ergebnisse/fair_wage_aequivalente/.
} 
through different sources including ILO, UNDP, OECD, the WageIndicator Foundation, Wikimedia Foundation, and other available literature.

The final result of the calculation is as follows:

$$
\mathrm{FWP}=\frac{4154}{1502} \times \frac{39}{37.5} \times(1-(0.27) 2)=2.66
$$

Incorporation of both parts of the equation (wage and time) and multiplying them permit their equal measurement within the mathematical calculation. In this way, two major interpretations can be highlighted. In the case of a process located in a country where the RW for the workers of that process is smaller than the MLW of the country, the outcome for $\mathrm{FWP}_{n}$ will be $<1$, thus illustrating more distance from the (minimum) subsistence level and results in lower FWP (Neugebauer et al. 2017). Second, in the case of equality between real and contracted working time, no effect can be seen on the FWP; however, if the RWT is larger than the CWT which illustrates the overtime work, the FWP will also be $<1$ and by more overtime works, it keeps going downwards (Neugebauer et al. 2017). Therefore, both parts of the characterization model are important factors showing the distance of the current performance from the minimum targeted levels at the location context. Accordingly, the turning point of 1 was defined by Neugebauer et al. (2017) representing that values $\geq 1$ are considered as to be fair because the real wage paid suits or is even more than the required minimum (living) wage. In our case, the value is 2.66 also reflecting that the salary is fair. As a result, all basic standards of living can be satisfied through the wage paid and positive direct impacts have resulted (score 3 , as indicated in Table 7).

\subsubsection{Health and safety of workers}

As Table 6 shows, the value for LTA frequency rate at the sector level (in the chemicals, plastics, and life sciences industry, including plastics and rubber processing) is already calculated for the year 2015 by the Federal Agency for Occupational Risks and reported in Essenscia (2017). The same figure was also reported for our case study throughout their yearly published report for the year 2015. Accordingly, the ratio between the company reported value for LTA (6.39) and sector value (9.2) is equal to $69.45 \%$ which falls within the level 3 of the scoring system introduced in Section 2 (Table 4). This shows a positive impact on the health and safety performance of the company (Table 6).

\subsubsection{Equal opportunities/discrimination for workers}

According to methodological sheets (UNEP/SETAC 2013) of SLCA and based on the results of the survey study (Rafiaani et al. 2019), "rate of female to male employee" is an important indicator to measure the performance of the company in providing equal opportunities for a broad population whatever their gender is. Actively enhancing equality at work also provides companies access to a wider range of potential workers. Equal opportunity for workers is, therefore, a relevant indicator for the social dimensions of sustainability. In the sector under consideration, the recent report provided by Essenscia (2017) highlighted that the percentage of employed women in the chemicals, plastics, and life sciences industry grew constantly from $23 \%$ in 2000 to $28 \%$ in 2015 . In the company under study, the most recent available data was from the year 2012 illustrating a 10\% share of women working in their company while comparing with the result at sector level for the same year with a share of $27.4 \%$; thus, the company receives a score of 1 (Table 6) for this indicator. The result shows that there is a room for enhancement of the company performance in promoting the share of women to increase this social indicator from the sustainability perspective.

\subsection{Semi-quantitative analysis results of applying SAM}

SAM was applied for analyzing the company performance over the production process in relation to the BR fulfillment introduced in the methodology section. By using a BR, the commitment to the subcategory in the company's policy, internal management, or strategy was assessed based on the

Table 6 Score calculations of the quantitative data in the worker's group of stakeholders

\begin{tabular}{|c|c|c|c|c|c|c|c|}
\hline Subcategory & Measurement & Unit & Sector $^{1}$ data & $\begin{array}{l}\text { Company }{ }^{2} \\
\text { data }\end{array}$ & $\begin{array}{l}\text { Social impact } \\
\text { percentage }(\%)\end{array}$ & Score & $\begin{array}{l}\text { Data } \\
\text { year }^{3}\end{array}$ \\
\hline Health and safety of workers & LTA & $\begin{array}{l}\text { per million hours } \\
\text { worked in } 2015\end{array}$ & 9.2 & 6.39 & 69.45 & 3 & 2015 \\
\hline Equal opportunities/discrimination for workers & $\begin{array}{l}\text { Percentage of } \\
\text { women employees }\end{array}$ & Percentage & 27.4 & 10 & 36.49 & 1 & 2012 \\
\hline
\end{tabular}

\footnotetext{
${ }^{1}$ The chemicals, plastics, and life sciences industry. Source: Essenscia (2017)

${ }^{2}$ Data were extracted from the yearly report of the company available online

${ }^{3}$ The most recent available data was used for each indicator. At the company level, the latest data for LTA was available for the year 2015 while the latest value on the women employees' share at the company only reported for the year 2012
} 
evidence company practices of the indicator associated with the subcategory. The results are presented in Table 7.
The value for "fair salary" from the worker stakeholder group was calculated in the previous section (Section 3.1.1)

Table 7 Results of SAM for the social performance of the company

\begin{tabular}{|c|c|c|c|c|}
\hline Stakeholder & Subcategory & Basic requirement (BR) & Evidence from company & Score \\
\hline Worker & Fair salary & $\begin{array}{l}\text { Based on the calculation for fair salary } \\
\text { introduced by Neugebauer et al. (2017), } \\
\text { values } \geq 1 \text { are considered as fair, as the } \\
\text { company paid wage fits or exceeds the } \\
\text { minimum living wage. }\end{array}$ & $\begin{array}{l}\text { The value is } 2.66 \text { also reflecting that } \\
\text { the salary is fair }\end{array}$ & $\begin{array}{l}3 \text { (satisfactory } \\
\text { performance) }\end{array}$ \\
\hline \multirow[t]{3}{*}{ Consumer } & $\begin{array}{l}\text { End of life } \\
\text { responsibility of } \\
\text { consumers }\end{array}$ & $\begin{array}{l}\text { Clear information provided by internal } \\
\text { management systems to consumers on } \\
\text { end-of-life options such as Product } \\
\text { Responsibility Performance Indicators, } \\
\text { PR4 (GRI 2006) or a recall policy for } \\
\text { its product at its end-of-life phase }\end{array}$ & $\begin{array}{l}\text { Not applicable since the biomass } \\
\text { produced is used mainly as animal } \\
\text { feed }\end{array}$ & $\begin{array}{l}3 \text { (satisfactory } \\
\text { performance }\end{array}$ \\
\hline & $\begin{array}{l}\text { Transparency of the } \\
\text { company }\end{array}$ & $\begin{array}{l}\text { Presence of social responsibility reports } \\
\text { such as corporate social responsibility } \\
\text { (CSR), social balance report, Global } \\
\text { Reporting Initiative (GRI), Accountability } \\
\text { 1000, Social Accountability } 8000, \\
\text { ISO 26000, or any other internationally } \\
\text { recognized documentation }\end{array}$ & $\begin{array}{l}\text { Company has a certificate of ISO } \\
\text { (9001:2015). The company has } \\
\text { committed to transparency as part } \\
\text { of its policy; it publishes its } \\
\text { sustainability report in line with } \\
\text { GRI guidelines }\end{array}$ & $\begin{array}{l}3 \text { (satisfactory } \\
\text { performance }\end{array}$ \\
\hline & $\begin{array}{l}\text { Consumers health } \\
\text { and safety }\end{array}$ & $\begin{array}{l}\text { Procedures regarding health and safety } \\
\text { standards. }\end{array}$ & $\begin{array}{l}\text { In } 2017 \text {, customer complaints were } \\
\text { at an all-time low of sixteen. With } \\
\text { this result, the company continues } \\
\text { this decrease since } 2015 \text {. All claims } \\
\text { result from an internal error } \\
\text { (wrong or missing label, wrong or } \\
\text { missing documents, wrong weight, } \\
\text { etc.) with no health and safety } \\
\text { consequences for the consumers. } \\
\text { Customers' concerns about their } \\
\text { track record and/or image concerning } \\
\text { corporate social responsibility are } \\
\text { illustrated by the growing number } \\
\text { of customer audits-three in } 2015 \text { - } \\
\text { about the topic. These audits are } \\
\text { related to issues like environmental } \\
\text { care, ethics, and working conditions. } \\
\text { Except for a few minor points for } \\
\text { improvement, everything reported } \\
\text { as fine }\end{array}$ & $\begin{array}{l}3 \text { (satisfactory } \\
\text { performance) }\end{array}$ \\
\hline \multirow[t]{3}{*}{$\begin{array}{l}\text { Local } \\
\text { community }\end{array}$} & $\begin{array}{l}\text { Safe and healthy living } \\
\text { conditions }\end{array}$ & $\begin{array}{l}\text { Evidence that the organization contributes } \\
\text { to the health of local communities } \\
\text { through environmental risk management } \\
\text { systems or through participation with } \\
\text { local companies in communicating the } \\
\text { potential health and safety impacts of their } \\
\text { operations on surrounding communities. }\end{array}$ & $\begin{array}{l}\text { In } 2017 \text {, the company has a 5-year } \\
\text { Global Prevention Plan, focusing } \\
\text { on operational and process safety, } \\
\text { protecting the environment, } \\
\text { wellbeing of people and focusing } \\
\text { on ergonomics. All this is } \\
\text { implemented via the annual action } \\
\text { plans, with one specific focus point } \\
\text { each year }\end{array}$ & 3 (satisfactory performance) \\
\hline & Secure living conditions & $\begin{array}{l}\text { Evidence of conflicts between the local } \\
\text { community and the company that may } \\
\text { put their secure living conditions at risk } \\
\text { (UNEP/SETAC 2009). }\end{array}$ & $\begin{array}{l}\text { There is no significant evidence of } \\
\text { conflicts with the local community } \\
\text { or any company performances that } \\
\text { put their secure living conditions } \\
\text { under risks }\end{array}$ & 3 (satisfactory performance) \\
\hline & Local employment & $\begin{array}{l}\text { Evidence that the company has a policy of } \\
\text { local hiring preferences. }\end{array}$ & $\begin{array}{l}\text { It has employees from the region } \\
\text { where the company site is located }\end{array}$ & 3 (satisfactory performance) \\
\hline
\end{tabular}


illustrating the fair wage paid at the sector level. Accordingly, the BR was fulfilled for this subcategory showing satisfactory performance. Similarly, the results of SAM for the company impacts on consumer and local community stakeholder groups were assessed positively, as the company presents evidence of a policy to fulfill the BRs for all their subcategories (Table 7), with an exclusion of the indicator for "end of life responsibility of consumers." This is not applicable in our case since the biomass produced is used mainly as animal feed and there is no need for information on the end-of-life options for consumers. Table 8 provides a summary of the performance assessment for all the indicators. It is clear that the company showed a satisfactory performance with regard to all the indicators except for the ratio of the employed women at the company. The company needs enhancement in its performance to better fulfill this indicator showing the commitment of the company with regard to equal opportunities.

\section{Discussion}

First, the main outcomes of the quantitative and semiquantitative analysis are highlighted. Next, the challenges of applying the SLCA approach at the company level are discussed and potential improvements are suggested.

\subsection{Interpretation of the results}

The studied company is, to a large extent, a chemical company and the algae biomass production process in this study was selected by the authors (and not by the company). Since the social performance approaches applied in this study focus on the behavior of the company during the production process and not the characteristics of the product itself, it is possible to extend our assessment to the whole social behavior of the company. This is in line with the SOLCA approach in which the organization is defined as the unit of analysis (and not a product) (Martínez-Blanco et al. 2015). Accordingly, data are basically associated with the company and the outcomes are reported based on the functional unit of analysis, i.e., the company under study.

In comparison with the economic or environmental impacts, the social impact encompasses a broad range of concerns and its indicators are usually difficult to determine (Chou et al. 2015). There is a need for companies to be informed of the most important indicators involved in a process that can better reflect its sustainability impacts (Chou et al. 2015). Since algal-based technologies still require advancements (Lardon et al. 2009), only a few indicators have been measured for pilot-scale systems or used for predicting commercialization scenarios. Falcone et al. (2019) referred to health and safety as one of the main issues associated with the impact of biobased products. For instance, accident rates related to the biomass production sectors such as agriculture and forestry in Germany are reported as rather high (Siebert et al. 2018). In our study, the company showed a satisfactory performance compared with the sector level with regard to the health and safety of the workers. Since considering the safety issues of the company is an important indicator affecting the social wellbeing of the workers, it is crucial to promote and monitor the occupational accident prevention measures applied by a company. Following the subcategory assessment method (SAM), in the annual report 2017 of the studied company, there was evidence of a 5-year Global Prevention Plan in the company, focusing on operational and process safety. In our analysis, the value for the fair salary indicator showed a positive performance of the company whereas the low rate of women employees of the company in comparison with the sector level reflects the need to promote the share of women. Another indicator of equal opportunity or anti-discrimination could be the existence of a policy or indication of hiring employees with disabilities (Wang et al. 2017). However, it was not possible to retrieve this information through the public information and annual reports of the company. According to the European Commission (2016), the share of women in labor market is influenced by the childcare services, the availability of flexible working time, and gender pay gaps between women and men. Fiscal (dis)incentives have also an effect on
Table 8 Summary of the company's performance (quantitative/semi-quantitative) assessment results for all social subcategories

\begin{tabular}{llc}
\hline Stakeholder & Subcategory & Score $^{\text {a }}$ \\
\hline Worker & Fair salary for workers & 3 \\
& Health and safety of workers & 3 \\
Consumer & Equal opportunities/discrimination for workers & 1 \\
& Transparency of the company & 3 \\
Local community & Consumers health and safety & 3 \\
& Safe and healthy living conditions & 3 \\
& Secure living conditions & 3 \\
& Local employment & 3
\end{tabular}

${ }^{\text {a }}$ Scores 1 (bad performance), 2 (inadequate performance), 3 (satisfactory performance), 4 (very good performance) 
female employment in Europe. Based on the studies conducted by Thévenon (2013) and Christiansen et al. (2016), raising the relative tax rate for second earners has a major negative effect on female employment in different European countries over the period 2002-2012.

In reference to the SAM, our results showed that the study case performs satisfactorily, obtaining a positive assessment by applying the SAM method. With regard to the consumer group, evidence exists that the company management systems ensure transparency as it has a formal report on social responsibility that includes a demonstration of the increased number of customer audits concerning subjects such as environmental care, working conditions, and ethics. Furthermore, there is no record of consumer complaints regarding health and safety violations. Falcone and Imbert (2018) also highlighted the necessity of including consumer-related indicators (i.e., transparency, consumers' health and safety, and end-of-life responsibility) in the SLCA for biobased products to be useful in market perception of such products. In their latest study, Falcone et al. (2019) discussed that insufficient public information regarding the potential impacts of the biobased products on health and environment may negatively influence on the consumers' willingness and demand for such products.

In assessing the company performance with regard to the local community, there was no evidence of conflicts with the local community neither that the company puts their secure living conditions and safety under risks. As mentioned earlier, the company has annual action plans, with one particular focus point each year. Through revisions and follow-up of the safety and risk assessments, the company systematically removes risks and takes efficient measures. Moreover, job creation is an important impact of the development of biobased industries (Ronzon et al. 2015; Falcone and Imbert 2018) and our analysis also showed that the company hires locally. As discussed by Siebert et al. (2018), one way that sustainable bioeconomy can support the rural and local communities' development is by creating employment opportunities in these regions. This can be supported through incentives to stay in the local region, which result in fewer migrations from the rural areas and assist in local communities' development. Therefore, the reported figure on the annual number of employment in companies can reveal their contribution to the economic development of the related production area.

It was difficult to evaluate how the company motivates its suppliers to meet the basic requirement (BR) introduced in SAM. This is in line with the study conducted by Lenzo et al. (2017) who also found similar results in their case studies within the textile sector in Italy, highlighting the lack of data availability for proving the company actions in promoting the BR of the indicators among its suppliers. As mentioned by Parent et al. (2013), if suppliers need to enhance their social performance, a competitive benefit is necessary so that they are encouraged to perform better. This can be done by the company actions on connecting the social enhancements via economic motivators (e.g., further con tracts with local suppliers and supplier awards). In total, as concluded by Martínez-Blanco et al. (2014), the possibility of making comparisons and the validity of the SLCA outcomes are significantly influenced by the selected approach for the assessment, the system boundaries, the stakeholders and indicators' selection, and the availability of data among others. The following section discusses the challenges encountered in applying the SLCA at the company level. Moreover, the needs for potential improvements and more feasible implementations of SLCA at the company level are highlighted.

\subsection{A critical view on social performance assessment at company level}

Based on our experience in conducting SLCA, there are several challenges among which data availability remains a major one. Schmidt et al. (2004) and Manhart and Grießhammer (2006) also concluded that data availability was a significant barrier in applying SLCA, which partly relates to the data collection at the company level. Zimmermann and Schomäcker (2017), who performed a review study on SLCA for early-stage $\mathrm{CO}_{2}$ utilization technologies, also concluded that there is a limited application of SLCA for such technologies because companies are not yet established or have recently been developed. The latter was the case for our analysis since the social data for such early-commercial stage technologies are mostly available for large-scale companies and mainly exist internally (site-specific or within a company at a corporate level). Therefore, it was not possible to access the detailed social information required for all the indicators only through the public sources available. Although the data for each indicator were collected for the same year at both levels (company and sector/country), it was not possible to collect the most recent available data for all indicator for the same year. For example, the latest data for LTA was available for the year 2015 while the latest value on the women employees' share at the company only reported for the year 2012. Similarly, Hannouf and Assefa (2018) encountered the same issue in conducting a SAM for social life cycle assessment. They referred to the difficulty in accessing the most recent data for indicators which resulted in using different time frames for some indicators. Thus, such data availability issues may limit the possibility of comparison between subcategories and indicators themselves. Therefore, to avoid any bias, our results should be interpreted at the company-level performance in general and not by making a comparison between different subcategories and indicators. The other aspect is related to the lack of data due to the lack of cooperation between the company and the supplier in gaining social data associated with their life cycle step (Traverso et al. 2018). This also refers 
to our analysis in the previous section, describing the difficulties in assessing the company behavior and attempts in encouraging its suppliers to fulfill the BF requirements of social performances. Thus, there is a need to improve transparency through more cooperation of the company with its suppliers in gaining social data and to refer to such cooperation in their annual sustainability and public reports.

From our experience, we could not scale the data and information for the consumer and local community stakeholder groups to the production process as it was done for the indicator of the worker group. Therefore, it was only possible to access general information to assess the company's performance at the local community level. To tackle the challenge of data availability, a dedicated database for SLCA needs to be established through a standard set of assessment indicators for which academic communities require more attempts in building up an agreement over a standard set of indicators. Moreover, further adoption of social performance assessments for all TRLs is needed by encouraging companies and research institutes to gather social data and create comprehensive databases and the possibility to access such detailed data. There are already a few generic data sources (at larger scale, i.e., sector, company, and international) such as the Product Social Impact Life Cycle Assessment (PSILCA) and Social Hotspots databases which still need improvements. In these databases, there is a lack of data for most of biobased industries and no data is available for CCU so far. In contrast, at the company level, first, more research needs to be conducted on collecting the social data through survey studies and interviews for which the collaboration of companies is a necessary requirement. Based on our experience, it is very challenging to convince companies to cooperate on data collection for their social performance assessment. Furthermore, there was a limitation to conduct a follow-up interview with the company to get more detailed information beyond the publicly available data due to, for example, time constraints at the company. Besides, company managers and innovative industry investors argue that, at the moment, the environmental and economic concerns are their first priorities and the social concerns in European countries are of less importance to be assessed for such lower TRL technologies. Nevertheless, Falcone et al. (2019) and Zimmermann and Schomäcker (2017) highlighted the importance of social assessment at the early stage of technology developments. The advantage of such results is that companies can use them to compare their performance with that of their specific sector and/or region in which they are active. Furthermore, this information can motivate decision-makers to make more efficient plans that positively address sustainability issues.

Another experience from our analysis is the generality of the indicators introduced within the UNEP/SETAC guidelines for SLCA and the subjectivity in data collection for the indicators in SAM. In their review study, Martin et al.
(2018) noticed that some commonly used indicators are mostly considered in the existing life cycle studies on biobased products whereas they identified other indicators as the important ones for life cycle sustainability assessment of biobased products. There should be particular regional definitions for specific indicators influencing data collection and uniformity because there are differences in regional regulations or practices (Traverso et al. 2018). This issue brings a difficulty in making a comparison between the results of SLCA for different companies that have the same production system but different social contexts. Such comparison would be unreliable if there is no specific definition of indicators along the life cycle of a product and based on each process. For example, the indicator for calculating the health and safety of workers may be defined differently among different regions as there is not yet a standardized approach for SLCA. This is also supported by Sousa-Zomer and Miguel (2018) who could use only a few indicators introduced by the UNEP/SETAC guidelines for the comparative analysis since only some of them could be related to the processes of each product system under their study. This point was addressed as well in the handbook of Product Social Impact Assessment (PSIA) for comparing the social performance of two or more products (Goedkoop et al. 2018). One solution would be to establish a reference scenario for each product/sector/process, as mentioned by Ciroth and Franze (2011). Indeed, when comparing several process/products together, it is not easy to define which one has a better social performance. The reason is that a social indicator can be positive and negative or even at the same time good or bad depending on the case study under assessment (Siebert et al. 2018). For some indicators, such as working hours, which affect fair wage, there is no defined threshold on how many hours are considered good or bad. This calls for further research on establishing a reference scenario in different sectors (Goedkoop et al. 2018).

Another limitation is related to applying SAM if the results are to be used for a comparison with other companies' performances. For example, SAM would not make any differences between the companies' performance if one company has more measurements and implementations fulfilling the defined BR than another company as both of them would be allocated to the same level (Ramirez et al. 2014). Therefore, there is a need to define new (sub)levels through which the differences between each level in SAM can be more precise. Moreover, allocation of fines to those companies applying only one measurement or having no sources (e.g., human, financial, and structure resources) can be a strategy for better performance and further development of companies. Moreover, the subjectivity in applying SAM is also an issue since the application may differ based on the data interpretations. This can be addressed by conducting a sensitivity analysis in comparative studies (Ramirez et al. 2014). 


\section{Conclusions}

This study underlines the possibilities and challenges of applying SLCA at the company level within the European context. A combined quantitative and semi-quantitative approach was used to assess the social performance of a Belgian company working with the algae biomass production system. The UNEP/SETAC (2009) guidelines and the subcategory assessment method (SAM) were considered as the basis of our analysis. Despite all the referred limitations, the combined assessment approach can be suitable for generating an overview of the potential social impacts of a production process. Our study highlighted the need for identifying specific indicators that provide more detailed analysis for the social impacts, as existing indicators are too general in a way that it brings difficulties to compare the social performance of companies operating in the same country/context. More detailed indicators require more detailed data and it is already difficult to obtain data at the company level even for current general indicators. Nevertheless, it is essential to point out that any attempt in conducting SLCA at lower TRL would be an added value since it helps to enrich the understandings and to identify the gaps in the existing knowledge regarding this growing field of research. Policy-makers may take the identified social impacts into account together with economic and environmental impacts when framing interventions in support of innovative companies. In this way, the beneficial sides to the society resulting from the innovation development are taken into consideration and publicity of such potential impacts may enhance the demand and reputation for innovative companies. One future challenge is the inclusion of the results from SLCA to a techno-economic assessment (TEA) model since many social and economic sustainability indicators for algae biomass production are closely correlated. For example, the health and safety measures for workers can influence the costs within a TEA. This integration is usually neglected in the existing assessments. It is important to point out that in our analysis, only some indicators along the production process were assessed due to the lack of site-specific data concerning all stakeholders and companies involved along the whole life cycle. This can be addressed, once all the necessary data are available for the entire life cycle to confirm the real social issues and to identify other challenges. Further practical implications regarding the application of the combined assessment approach through covering the referred limitations in our study are highlighted as follows:

- Understanding possible risks and opportunities from the social perspective in the initial development phase of a production process;

- Evaluating the social impact of a company performance for internal assessment and optimization;
- Enhancing the communication within a supply chain and business partners by providing reports on the social performance and the need for sharing/providing data sources and developing databases;

- Screening the production process to determine main social impacts, risks, and improvement possibilities that might influence further steps throughout a supply chain not only from a social aspect but also from an economic aspect since several social impacts have an economic background.

\section{References}

Abdul Hamid NN, Lim JS (2018) Techno-economic assessment of an integration of algae-based biorefinery with palm oil mill. Chem Eng Trans 63:169-174. https://doi.org/10.3303/CET1863029

Alvarez-ChÁvez CR, Edwards S, Moure-Eraso R, Geiser K (2012) Sustainability of bio-based plastics: general comparative analysis and recommendations for improvement. J Clean Prod 23:47-56

Anker R (2011) Estimating a living wage: a methodological review. International Labour Office, Geneva

Aparcana S, Salhofer S (2013) Application of a methodology for the social life cycle assessment of recycling systems in low income countries: three Peruvian case studies. Int J Life Cycle Assess 18(5):1116-1112

Baumann H, Tillman A (2004) The hitchhiker's guide to LCA: an orientation in life cycle assessment methodology and application. Studentlitteratur, Lund

Benoît C, Norris GA, Valdivia S, Ciroth A, Moberg A, Bos U, Prakash S, Ugaya C, Beck T (2010) The guidelines for social life cycle assessment of products: just in time!. Int J Life Cycle Assess 15(2):156163

Bouzid A, Padilla M (2014) Analysis of social performance of the industrial tomatoes food chain in Algeria. Mediterranean journal of economics, agriculture and environment. New Medit 13(1):60-65

Campbell PK, Beer T, Batten D (2011) Life cycle assessment of biodiesel production from microalgae in ponds. Bioresour Technol 102(1): $50-56$

Chang Y-C, Wang J-D (1995) Cumulative injury rate and potential workdays and salary lost. Scand J Work Environ Health 21(6):494-503

Chhipi-Shrestha GC, Rehan Sadiq KH (2015) 'Socializing' sustainability: a critical review on current development status of social life cycle impact assessment method. Clean Techn Environ Policy 17:579596

Chou C-J, Chen C-W, Conley C (2015) An approach to assessing sustainable product-service systems. J Clean Prod 86:277-284

Christiansen L, Lin H, Pereira J, Topalova P, Turk R (2016) Individual choice or policies? Drivers of female employment in Europe. IMF Working Paper WP/16/49, Washington D.C

Ciroth A, Franze J (2011) LCA of an ecolabeled notebook: consideration of social and environmental impacts along the entire life cycle. GreenDeltaTC GmbH, Berlin

Daroch M, Geng S, Wang G (2013) Recent advances in liquid biofuel production from algal feedstocks. Appl Energ 102:1371-1381

Dreyer L, Hauschild M, Schierbeck J (2006) A framework for social life cycle impact assessment. Int J Life Cycle Assess 11(2):88-97

Dreyer L, Hauschild M, Schierbeck J (2010) Characterisation of social impacts in LCA. Part. 2: implementation in six company case studies. Int J Life Cycle Assess 15:385-402 
Economic Commission for Europe (2018) idelines on producing leading, composite and sentiment indicators - draft. Conference of European Statisticians, Sixty-sixth plenary session, Geneva, 18-20 June 2018. https://www.unece.org/fileadmin/DAM/stats/documents/ece/ces/ 2018/CES 7-Guidelines_on_LCS_indicators_for_CES_Interim consultation_for_upload.pdf Accessed 22 Aug 2019

Efroymson RA, Dale VH, Langholtz MH (2017) Socioeconomic indicators for sustainable design and commercial development of algal biofuel systems. GCB Bioenergy 9:1005-1023

Ekener-Petersen E, Finnveden G (2013) Potential hotspots identified by social LCA - part 1: a case study of a laptop computer. Int J Life Cycle Assess 18:127-143

Ekener-Petersen E, Höglund J, Finnveden G (2014) Screening potential social impacts of fossil fuels and biofuels for vehicles. Energ Policy $73: 416-426$

Essencia (2017) Sustainable development report 2017 of the Belgian chemicals, plastics and life sciences industry. www. essensciaforsustainability.be. Accessed 21 Jan 2019

European Commission (2016) Labour force participation of women. European Semester Thematic Factsheet. Nov 14. https://ec.europa. eu/info/sites/info/files/european-semester_thematic-factsheet_ labour-force-participation-women en.pdf. Accessed 10 Feb 2019

Falcone PM, Imbert E (2018) Social life cycle approach as a tool for promoting the market uptake of bio-based products from a consumer perspective. Sustainability 10(4):1031. https://doi.org/10.3390/ su10041031

Falcone PM, González García S, Imbert E et al (2019) Transitioning towards the bioeconomy: assessing the social dimension through a stakeholder lens. Corp Soc Resp Environ Ma 1-19. https://doi.org/ $10.1002 / \mathrm{csr} .1791$

FAO (Food and Agriculture Organization of the United Nations) (2006) Inequality analysis; The Gini index. http://www.fao.org/3/aam352e.pdf\%20 Accessed 09 Feb 2019

Foolmaun RK, Ramjeeawon T (2013) Comparative life cycle assessment and social life cycle assessment of used polyethylene terephthalate (PET) bottles in Mauritius. Int J Life Cycle Assess 18:155-171

Franze J, Ciroth A (2011) A comparison of cut roses from Ecuador and the Netherlands. Int J Life Cycle Assess 16:366-379

Garrido SR, Parent J, Beaulieu L, Revéret J-P (2018) A literature review of type I SLCA - making the logic underlying methodological choices explicit. Int J Life Cycle Assess 23(3):432-444

Global Reporting Initiative (GRI) (2006) Sustainability Reporting Guidelines, Amsterdam

Gnansounou E, Raman JK (2016) Life cycle assessment of algae biodiesel and its co products. Appl Energ 161:300-308

Greco S, Ishizaka A, Tasiou M, Torrisi G (2019) On the methodological framework of composite indices: a review of the issues of weighting, aggregation, and robustness. Soc Indic Res 141(1):61-94

Goedkoop MJ, Indrane D, de Beer IM (2018) Product social impact assessment handbook-2018 Amersfoort, September 1st, 2018. https://product-social-impact-assessment.com.

Gouveia L, Batista AP, Sousa I, Raymundo A, Bandarra NM (2008) Chapter 2. Microalgae in novel food products. In: Food Chemistry Research Developments. https:/www.repository.utl.pt/bitstream/ 10400.5/2434/1/REP-I.Sousa-CapLivro\%20algasGouveia.pdf. Accessed 04 Feb 2019

Guzi M, Kahanec M (2018) Estimating living wage globally. Amsterdam, WageIndicator Foundation, December. https://wageindicator.org/ documents/publicationslist/publications-2018/living-wage_ english_20181221.pdf. Accessed 24 Oct 2019

Handler RM, Shonnard DR, Kalnes TN, Lupton FS (2014) Life cycle assessment of algal biofuels: influence of feedstock cultivation systems and conversion platforms. Algal Res 4:105-115

Hannouf M, Assefa G (2018) Subcategory assessment method for social life cycle assessment: a case study of high-density polyethylene production in Alberta, Canada. Int J Life Cycle Assess 23(1):116132

Hasenheit M, Gerdes H, Kiresiewa Z, Beekman V (2016) Summary report on the social, economic and environmental impacts of the bioeconomy. http://www.biostep.eu/fileadmin/BioSTEP/Bio documents/BioSTEP_D2.2_Impacts_of_the_bioeconomy.pdf. Accessed 10 Feb 2019

Hosseinijou S, Mansour S, Shirazi M (2014) Social life cycle assessment for material selection: a case study of building materials. Int J Life Cycle Assess 19:620-645

Idris MNM, Hashim H, Lim JS, Ho CS (2017) Economic assessment of microalgae-based $\mathrm{CO} 2$ utilization in power plant sector in Malaysia. Chem Eng Trans 56:643-648

ISO (2006) Environmental management — life cycle assessment - principles and framework. International Organization of Standardization

ISO (2010) Guidance on social responsibility. https://www.iso.org/ standard/42546.html Accessed 14 April 2019

Jørgensen A, Le BA, Nazarkina L, Hauschild MZ (2008) Methodologies for social life cycle assessment. Int J Life Cycle Assess 13(2):96103

Khan MI, Shin JH, Kim JD (2018) The promising future of microalgae: current status, challenges, and optimization of a sustainable and renewable industry for biofuels, feed, and other products. Microb Cell Fact 17(1):36

Koller M, Salerno A, Tuffner P et al (2012) Characteristics and potential of microalgal cultivation strategies: a review. J Clean Prod 37:377388

Lardon L, Hélias A, Sialve B, Steyer J-P, Bernard O (2009) Life-cycle assessment of biodiesel production from microalgae. Environ Sci Technol 43:6475-6481

Lenzo P, Traverso M, Salomone R, Ioppolo G (2017) Social life cycle assessment in the textile sector: an Italian case study. Sustainability 9:2092. https://doi.org/10.3390/su9112092

Madugu FU (2015) Modelling and analysis of the techno-economic and social impacts of an algal oil production facility. School of Energy, Environment and Agrifood Offshore Renewable and Energy Engineering, Cranfield University

Manhart A, Grießhammer R (2006) Social impacts of the production of notebook PCs - contribution to the development of a product sustainability assessment (PROSA). http://www.prosa.org/fileadmin/ user_upload/pdf/notebooksurvey_final_engl.pdf. Accessed 09 Feb $\overline{2} 019$

Manik Y, Leahy J, Halog A (2013) Social life cycle assessment of palm oil biodiesel: a case study in Jambi Province of Indonesia. Int J Life Cycle Assess 18(7):1386-1392

Martin M, Røyne F, Ekvall T, Moberg A (2018) Life cycle sustainability evaluations of bio-based value chains: reviewing the indicators from a Swedish perspective. Sustainability 10(2):547. https://doi.org/10. 3390/su10020547

Martínez-Blanco J, Lehmann A, Muñoz P, Antón A, Traverso M, Rieradevall J, Finkbeiner M (2014) Application challenges for the social LCA of fertilizers within life cycle sustainability assessment. J Clean Prod 69:34-48

Martínez-Blanco J, Lehmann A, Chang Y-J, Finkbeiner M (2015) Social organizational LCA (SOLCA) - a new approach for implementing social LCA. Int J Life Cycle Assess 20:1586-1599

Menetrez MY (2012) An overview of algae biofuel production and potential environmental impact. Environ Sci Technol 46:7073-7085

Méthot A (2005) FIDD: a green and socially responsible venture capital fund. Presentation on the Life Cycle Approaches for Green Investment-26th LCA Swiss Discussion Forum, 2005, Lausanne, Switzerland

Montero MJ, Araque RA, Rey JM (2009) Occupational health and safety in the framework of corporate social responsibility. Saf Sci 47(10): $1440-1445$ 
Musaazi MK, Mechtenberg AR, Nakibuule J, Sensenig R, Miyingo E, Makanda JV, Hakimian A, Eckelman MJ (2015) Quantification of social equity in life cycle assessment for increased sustainable production of sanitary products in Uganda. J Clean Prod 96:569-579

Nef (2004) Measuring social impact: the foundation of social return on investment (SROI). http://with-one-voice.com/sites/default/files/ London\%20Business \%20School\%20\%20Measuring\%20social\% 20impact_0.pdf. Accessed 18 Feb 2019

Neugebauer S, Traverso M, Scheumann R, Chang Y-J, Wolf K, Finkbeiner M (2014) Impact pathways to address social well-being and social justice in SLCA-fair wage and level of education. Sustainability 6:4839-4857

Neugebauer S, Emara Y, Hellerström C, Finkbeiner M (2017) Calculation of fair wage potentials along products' life cycle-introduction of a new midpoint impact category for social life cycle assessment. J Clean Prod 143(1):1221-1232

NRC (2012) Sustainable development of algal biofuels in the United States. Committee on the Sustainable Development of Algal Biofuels. National Research Council of the National Academies. The National Academies Press, Washington, DC

Ofori Agyekum E, Fortuin KPJ, van der Harst E (2017) Environmental and social life cycle assessment of bamboo bicycle frames made in Ghana. J Clean Prod 143:1069-1080

Omann I (2007) A multicriteria tool for evaluating the impacts of product service systems on sustainable development: an application in Austrian companies. SERI Working paper 5:1-28

Parent J, Cucuzzella C, Revéret J-P (2010) Impact assessment in SLCA: sorting the sLCIA methods according to their outcomes. Int J Life Cycle Assess 15:164-171

Parent J, Cucuzzella C, Reveret J (2013) Revisiting the role of LCA and SLCA in the transition towards sustainable production and consumption. Int J Life Cycle Assess 18(9):1642-1652

Petti L, Ramirez PKS, Traverso M, Ugaya CML (2018) An Italian tomato "Cuore di Bue" case study: challenges and benefits using subcategory assessment method for social life cycle assessment. Int J Life Cycle Assess 23(3):569-580

Plaza M, Herrero M, Cifuentes A, Ibanez E (2009) Innovative natural functional ingredients from microalgae. J Argic Food Chem 57: 7159-7170

Prasara-A J, Gheewala SH (2018) Applying social life cycle assessment in the Thai sugar industry: challenges from the field. J Clean Prod 172:335-346

Rafiaani P, Kuppens T, Van Dael M, Azadi H, Lebailly P, Van Passel S (2018) Social sustainability assessments in the biobased economy: towards a systemic approach. Renew Sust Energ Rev 82(2):18391853

Rafiaani P, Dikopoulou Z, Van Dael M, Kuppens T, Azadi H, Lebailly P, Van Passel S (2019) Identifying social indicators for sustainability assessment of CCU technologies: a modified multi-criteria decision making technique. Soc Indic Res. https://doi.org/10.1007/s11205019-02154-4

Raj-Reichert G (2013) Safeguarding labour in distant factories: health and safety governance in an electronics global production network. Geoforum 44:23-31

Ramirez PKS, Petti L, Haberland NT, Ugaya CML (2014) Subcategory assessment method for social life cycle assessment. Part 1: methodological framework. Int J Life Cycle Assess 19:1515-1523

Ramirez PKS, Petti L, Brones F, Ugaya CML (2016) Subcategory assessment method for social life cycle assessment. Part 2: application in Natura's cocoa soap. Int J Life Cycle Assess 21:106-117

Rizwan M, Lee JH, Gani R (2015) Optimal design of microalgae-based biorefinery: economics, opportunities and challenges. Appl Energ 150:69-79

Ronzon T, Santini F, M'Barek R (2015) The bioeconomy in the European Union in numbers. Facts and figures on biomass, turnover and employment; European Commission, Joint Research Centre, Institute for Prospective Technological Studies: Seville, Spain

Schmidt I, Meurer M, Saling P, Kicherer A, Reuter W, Gensch C (2004) SEEbalance - managing sustainability of products and processes with the socio-eco-efficiency analysis by BASF. Green Manage Int 45:79-94

Siebert A, Bezama A, O'Keeffe S, Thrän D (2018) Social life cycle assessment indices and indicators to monitor the social implications of wood-based products. J Clean Prod 172:4074-4084

Sousa-Zomer TT, Miguel PLC (2018) The main challenges for social life cycle assessment (SLCA) to support the social impacts analysis of product-service systems. Int J Life Cycle Assess 23(3):607-616

Spierling S, Knüpffer E, Behnsen H, Mudersbach M, Krieg H, Springer S, Albrecht S, Herrmann C, Endres H-J (2018) Bio-based plastics A review of environmental, social and economic impact assessments. J Clean Prod 185:476-491

Spillemaeckers S, Vanhoutte G, Taverniers L, Lavrysen L, van Braeckel D, Mazijn B, Rivera JD (2004) Integrated product assessment - the development of the label 'Sustainable Development' for products ecological, social and economical aspects of integrated product policy. Belgian Science Policy, Brussels

Spruijt J (2017) Market analysis and competitiveness of the PUFAChain in 'van der Voort MPJ, Spruijt J, Potters J, de Wolf PL, Elissen HJH (2017) Socio-economic assessment of Algae-based PUFA production' Public Output report of the PUFAChain project, Göttingen, December 2017, 79 pp. www.pufachain.eu. Accessed 10 Feb 2019

Telles do Carmo BB, Margni M, Baptiste P (2016) Social impacts profile of suppliers: a S-LCA approach. IFAC PapersOnLine 49(2):36-41

Thévenon O (2013) Drivers of female labour force participation in the OECD. OECD Social, Employment and Migration Working Papers No. 145, OECD Publishing

Thomassen G, Egiguren Vila U, Van Dael M et al (2016) A technoeconomic assessment of an algal-based biorefinery. Clean Technol Environ 18:1849. https://doi.org/10.1007/s10098-016-1159-2

Thomassen G, Van Dael M, Van Passel S (2018) The potential of microalgae biorefineries in Belgium and India: an environmental techno-economic assessment. Bioresour Technol 267:271-280

Traverso M, Asdrubali F, Francia A, Finkbeiner M (2012a) Towards life cycle sustainability assessment: an implementation to photovoltaic modules. Int J Life Cycle Assess 17(8):1068-1079

Traverso M, Finkbeiner M, Jørgensen A, Schneider L (2012b) Life cycle sustainability dashboard. J Ind Ecol 16:680-688

Traverso M, Bell L, Saling P, Fontes J (2018) Towards social life cycle assessment: a quantitative product social impact assessment. Int $\mathrm{J}$ Life Cycle Assess 23:597-606

Ugaya C, Brones F, Corrêa S (2011) S-LCA: preliminary results of Natura's cocoa soap bar. Proceedings of Life Cycle Mangement conference, 2011, Berlin

UNDP (2018) http://hdr.undp.org/en/data. Accessed 11 Oct 2018

UNEP/SETAC (2013) The methodological sheets for subcategories in social life cycle assessment (S-LCA). UNEP-SETAC Life Cycle Initiative, Paris. https://www.lifecycleinitiative.org/wp-content/ uploads/2013/11/S-LCA methodological sheets 11.11.13.pdf. Accessed 07 Feb 2019

UNEP-SETAC (2009) Guidelines for social life cycle assessment of products. United Nations Environmental Programme. Belgium: Druk in der weer. http://www.unep.fr/shared/publications/pdf/ dtix1164xpa-guidelines_slca.pdf. Accessed 16 Feb 2019

van Haaster B, Ciroth A, Fontes J, Wood R, Ramirez A (2017) Development of a methodological framework for social life-cycle assessment of novel technologies. Int J Life Cycle Assess 22(3): 423-440

Vinyes E, Oliver-Solà J, Ugaya C, Rieradevall J, Gasol C (2013) Application of LCSA to used cooking oil waste management. Int J Life Cycle Assess 18:445-455 
WageIndicator Foundation (2018) WageIndicator.org. https:// wageindicator.org/salary/wages-in-context. Accessed 18 March 2019

Wang S-W, Hsu C-W, Hu A-H (2016) An analytic framework for social life cycle impact assessment - part 1: methodology. Int J Life Cycle Assess 21:1514-1528

Wang S-W, Hsu C-W, Hu AH (2017) An analytical framework for social life cycle impact assessment - part 2: case study of labor impacts in an IC packaging company. Int J Life Cycle Assess 22(5):784-797

WBCSD (World Business Council for Sustainable Development) ( (2016) Social life cycle metrics for chemical products) Social life cycle metrics for chemical products. November 2016, Geneva, Switzerland. https://www.wbcsd.org/Projects/Chemicals/ Resources/Social-Life-Cycle-Metrics-for-Chemical-Products. Accessed 13 Feb 2019

WHO (2019) Age standardized disability-adjusted life year (DALY) rate (per 100000 population). http://www.who.int/healthinfo/global_ burden_disease/metrics_daly/en/. Accessed 24 Oct 2019

Wilson MH, Mohler DT, Groppo JG, Grubbs T, Kesner S, Frazar EM, Shea A, Crofcheck C, Crocker M (2016) Capture and recycle of industrial $\mathrm{CO}_{2}$ emissions using microalgae. Appl Petrochem Res 6(3):279-293

Wu W, Lin K-H, Jo-Shu C (2018) Economic and life-cycle greenhouse gas optimization of microalgae-to-biofuels chains. Bioresour Technol 267:550-559

Yang Y, Zhang B, Cheng J, Pu S (2015) Socio-economic impacts of algae-derived biodiesel industrial development in China: an inputoutput analysis. Algal Res 9:74-81

Zimmermann AW, Schomäcker R (2017) Assessing early-stage CO utilization technologies-comparing apples and oranges? Energy Technol 5(6):850-860

Zamalloa C, Vulsteke E, Albrecht J et al (2011) The techno-economic potential of renewable energy through the anaerobic digestion of microalgae. Bioresour Technol 102:1149-1158

Zhu L, Huo S, Qin L (2015) A microalgae-based biodiesel refinery: sustainability concerns and challenges. Int J Green Energy 12: 595-602

Publisher's note Springer Nature remains neutral with regard to jurisdictional claims in published maps and institutional affiliations. 